\title{
Proximate and Free Amino Acid Composition during Development of Fruit Body of Kuroawabitake (Pleurotus abalonus Han, Chen et Cheng)
}

\author{
Takeo TABATA ${ }^{1}$ and Tetsuya OGURA ${ }^{2}$ \\ ${ }^{1}$ Kobe Women's University Seto Junior College, 721 Kannonji, Seto-cho, Akaiwa-gun, Okayama 709-0863, Japan \\ ${ }^{2}$ Universidad Autonoma de Guadalajara, Departamento de Quimica, CEN, Apdo Postal 1-440, Guadalajara, Jalisco, Mexico
}

Received May 13, 2003; Accepted October 21, 2003

\begin{abstract}
Kuroawabitake (Pleurotus abalonus) were divided into two parts during development of fruit body: coremia (black-headed coremioid) and fruit body. The proximate compositions and free amino acids were determined. There was no marked difference between the coremia and fruit body in proximate composition of protein and carbohydrate (dry weight). The fruit body was high in moisture and fat, whereas the ash was high in coremia. The fruit body contained higher amounts of total free amino acids than the coremia. The contents of monosodium glutamate-like components, including aspartic and glutamic acids, were high in fruit body, and the two parts were considerably different tasting in their amino acids.
\end{abstract}

Keywords: Kuroawabitake (Pleurotus abalonus), coremia, fruit body, proximate composition, free amino acid

The Kuroawabitake mushroom (Pleurotus abalonus (Han, Chen et Cheng)) is also called an abalone mushroom. Morphologically, P. abalonus is characterized by the formation of black coremia at the base of the stem, black pileus, and brownish lamellae (Miller, 1969; Jong \& Peng, 1975; Neda \& Furukawa, 1987).

The strain of P. abalonus was introduced from Taiwan and the sawdust-based cultivation was started in Okinawa Pref. Research on the cultural characteristics (Kinjo et al., 1992; Takayama et al., 1993; Ohga, 2000) and biological activities (Tamaki et al., 1997, 2002) of this mushroom has been reported.

$P$. abalonus have gradually become popular in Japan recently due to their delicious and unique texture.

In many parts of Japan, mushrooms have been part of the human diet for a long time. Mushrooms are nutritionally very important since most of them have a very high protein content, in comparison to vegetables (Kagakugijutsucho Shigen-chousakai, 2001). It is also known that free amino acids such as glutamic and aspartic acids in mushrooms play an important role in the overall taste. Numerous papers describe the constituent changes in the stages of fruit body formation of the edible mushroom (Kazuno \& Miura, 1984, 1985; Muratsubaki et al., 1986; Yoshida et al., 1986, 1987; Tabata \& Yamasaki, 1995; Mau et al., 1998). However, the change in components during development of the fruit body of P. abalonus is unknown.

Our objective was to examine the proximate and free amino acid compositions in the parts of coremia (note: coremia is characterized by its black-headed coremioid imperfect state which is produced abundantly in culture) and fruit body of $P$. abalonus as shown in Figs. 1-3.
Materials and methods

Cultivation of $P$. abalonus The strain of $P$. abalonus was purchased from Onuki Kinjin Co., Utsunomiya-shi.

The sawdust mixture was composed of $75 \%(\mathrm{w} / \mathrm{w})$ hardwood sawdust from beech, $20 \%(\mathrm{w} / \mathrm{w})$ rice bran, and $5 \%(\mathrm{w} / \mathrm{w})$ corn flour. Tap water was added to the mixture to adjust the water content to about $70 \%$. Substrate $(1.2 \mathrm{~kg}$, wet weight) was packed into a heat resistant polyethylene bag, which was then sealed with a cap.

Bags containing substrate were sterilized at $121^{\circ} \mathrm{C}(1.1 \mathrm{~atm})$ for $2 \mathrm{~h}$, then allowed to cool overnight. Each substrate block was inoculated with $10 \mathrm{~g}$ of solid sawdust spawn. Inoculated bags of substrate were incubated at $25^{\circ} \mathrm{C}$ in the dark. When the substrate was fully colonized by the fungal mycelia, that is, after a period of 4 to 5 weeks, they were transferred into a cultivation chamber and the bag was opened. In order to facilitate primordial induction, the temperature was maintained at $23-25^{\circ} \mathrm{C}$, the relative humidity was adjusted at $90 \%$, and the light intensity at 300-400 lux for $24 \mathrm{~h}$.

The samples taken as specimens were divided into two parts, coremia and fruit body. Each sample was dried in a forced airoven at $50-60^{\circ} \mathrm{C}$ for $70 \mathrm{~h}$. Dried samples were ground in a stainless steel mill to obtain a homogeneous sample.

Proximate composition The moisture, protein, fat, fiber and ash were estimated according to the conventional method (Sugahara, 1995). The use of common factor 6.25 in protein analysis for mushrooms containing more nonprotein may result in overestimation of protein content. Therefore, the averaged value of 3.99 derived from total nitrogen and amino acid nitrogen data of mushrooms was used (Ogawa, 1994; Fujihara et al., 1995). The amount of carbohydrate was estimated by subtracting the amount of protein, fat and ash from $100 \%$.

Analysis of free amino acid One gram of dried mushroom powder was shaken with $25 \mathrm{ml}$ of $10 \%$ (w/v) sulfosalicylic acid 


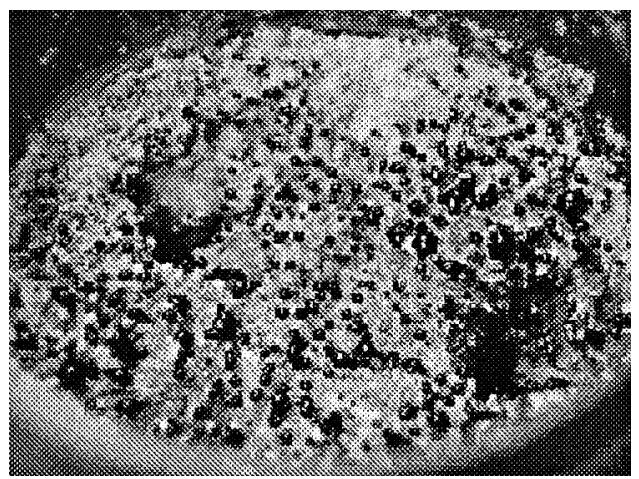

Fig. 1. Coremia of Pleurotus abalonus on sawdust medium.

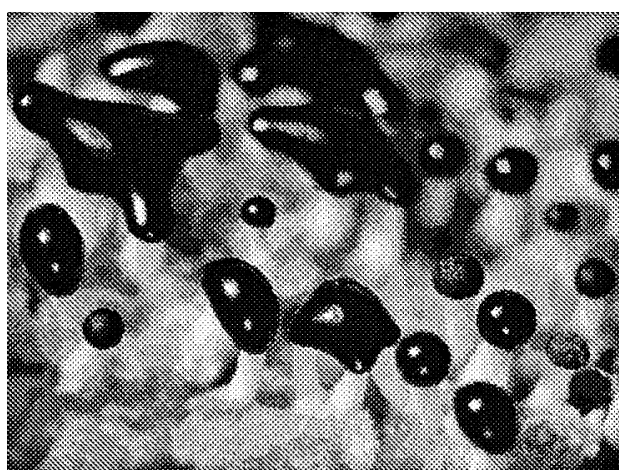

Fig. 2. Coremia of Pleurotus abalonus on sawdust medium (a stereoscopic microscope photograph).

(Wako Pure Chemical Industries Co., Osaka) for $20 \mathrm{~min}$ at ambient temperature and filtered through Whatman No.4 filter paper. The filtrate was adjusted to $\mathrm{pH} 2.2$ with $3 \mathrm{~N} \mathrm{NaOH}$ and made up to $100 \mathrm{ml}$ with sodium citrate buffer (Wako). One milliliter of the extract was diluted to $5 \mathrm{ml}$ and filtered through a Millipore LH nonsterile filter $(0.45 \mu \mathrm{m})$. The diluted filtrate was mixed with $o$ phthalaldehyde reagent (Wako) in an Eppendorf tube, shaken to facilitate derivatization, and then immediately injected onto the high-performance liquid chromatograph (HPLC). A Shimadzu LC-6A equipped with fluorescence detector, with fluorescence excitation at $348 \mathrm{~nm}$ and emission at $450 \mathrm{~nm}$, and a Shim-pack ISC-07/S $1504 \mathrm{Na}$ column (Shimadzu) was used. Each amino acid was quantified by a calibration curve of the authentic amino acid.

\section{Results and Discussion}

Fruit body contained higher moisture and fat than coremia, although the ash was low. Coremia contained low amounts of fat but high amounts of ash. Both coremia and fruit body had the same degree of protein and carbohydrate contents. Generally, mushrooms are a good source of protein, and their protein contents range from 10 to $35 \%$ of dry weight (Kurasawa et al., 1982). The protein content in the two parts was within this range. The lipid contents in other species of Pleurotus range from 1.7 to $4.5 \%$ on a dry basis (Kurasawa et al., 1982). The lipid contents in the two parts of $P$. abalonus were within this range. The carbohydrate contents in other species of Pleurotus range from 56.9 to

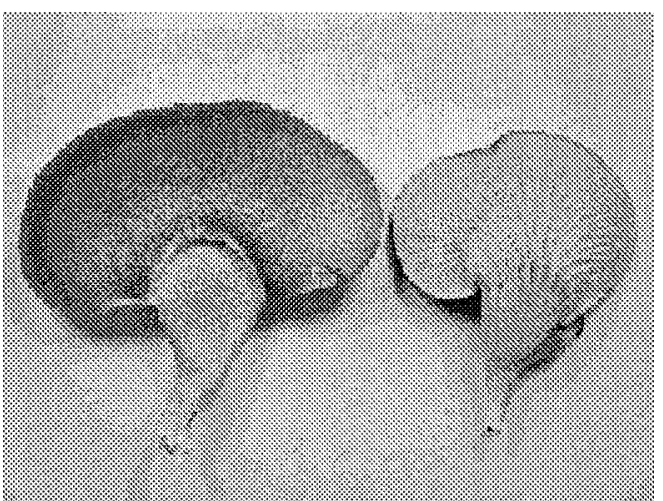

Fig. 3. Fruit bodies of Pleurotus abalonus.

$66.8 \%$ on a dry basis (Kurasawa et al., 1982). The carbohydrate contents in the two parts of $P$. abalonus were slightly higher than this range. However, the carbohydrate was estimated by subtracting the protein and others from the whole sample. Therefore, the observed high carbohydrate contents in this study are partly responsible for the lower protein estimated using the conversion factor of 3.99 (Table 1).

Fifteen free amino acid contents are shown in Table 2. The coremia and fruit body contained 23.37 and $27.91 \mathrm{mg} / \mathrm{g}$ of total free amino acids based on dry weight, respectively. The contents of total free amino acid in the two parts were notably higher than those found in Shiitake mushroom (Lentinus edodes) (16.65$21.12 \mathrm{mg} / \mathrm{g}$ ) (Terashita et al., 1990; Kiribuchi, 1991). The contents were similar to those in Enokitake (Flammulina velutipes) (27.85 mg/g) but much lower than those in Hiratake (Pleurotus ostreatus ) (63.23 mg/g) (Kiribuchi, 1991).

The monosodium glutamate-like components, including aspartic and glutamic acid, were about 1.7 times (75\%) higher in fruit body, $6.29 \mathrm{mg} / \mathrm{g}$, than the coremia, $3.59 \mathrm{mg} / \mathrm{g}$. The MSGlike components in fruit body were higher than those in Shiitake mushroom (4.78-4.81 mg/g) (Terashita et al., 1990; Kiribuchi, 1991), whereas those in the coremia were lower than those in Shiitake, Hiratake $(8.78 \mathrm{mg} / \mathrm{g})$, and Enokitake $(4.55 \mathrm{mg} / \mathrm{g})$ (Kiribuchi, 1991).

The sweet taste components showed no marked differences in threonine, proline, glycine and serine between the coremia and fruit body. However, the content of alanine was much higher in the fruit body. Therefore, 1.1 times more of the sweet tasting amino acids were contained in the fruit body than in the coremia.

Table 1. Proximate compositions in the coremia and fruit body of $P$. abalonus.

\begin{tabular}{lcc}
\hline & \multicolumn{2}{c}{ Content $(\%)^{a)}$} \\
\cline { 2 - 3 } & \multicolumn{1}{c}{ Coremia } & Fruit body \\
\hline Moisture & $87.51 \pm 1.61$ & $90.96 \pm 1.71$ \\
Protein $^{b)}$ & $2.31 \pm 0.01(18.49)$ & $1.71 \pm 0.01(18.81)$ \\
Fat & $0.24 \pm 0.03(1.92)$ & $0.33 \pm 0.04(3.65)$ \\
Carbohydrate & $8.77 \pm 0.42(70.22)$ & $6.37 \pm 0.45(70.46)$ \\
Ash & $1.17 \pm 0.03(9.37)$ & $0.64 \pm 0.03(7.08)$ \\
\hline
\end{tabular}

${ }^{a)}$ Mean \pm standard deviation $(n=3)$. Numbers in parenthesis indicate the percentage on a dry basis. ${ }^{b)}$ The nitrogen factor used for protein calculation was 3.99 . 
Table 2. Taste characteristics of free amino acids in the two parts of $P$. abalonus.

\begin{tabular}{lcc}
\hline \multirow{2}{*}{ Taste characteristic } & \multicolumn{2}{c}{ Content $(\mathrm{mg} / \mathrm{g}, \text { dry weight })^{a)}$} \\
\cline { 2 - 3 } MSG-like & $(3.59 \pm 0.04)$ & Fruit body \\
\hline L-Aspartic acid & $1.16 \pm 0.03$ & $(6.29 \pm 0.03)$ \\
L-Glutamic acid & $2.43 \pm 0.04$ & $1.81 \pm 0.02$ \\
Sweet & $(4.70 \pm 0.02)$ & $4.48 \pm 0.03$ \\
L-Alanine & $1.35 \pm 0.04$ & $(5.16 \pm 0.01)$ \\
Glycine & $0.46 \pm 0.01$ & $2.49 \pm 0.01$ \\
L-Proline & $0.55 \pm 0.02$ & $0.54 \pm 0.01$ \\
L-Serine & $1.16 \pm 0.02$ & $0.56 \pm 0.01$ \\
L-Threonine & $1.18 \pm 0.01$ & $0.82 \pm 0.01$ \\
Bitter & $(13.98 \pm 0.03)$ & $0.75 \pm 0.01$ \\
L-Arginine & $10.82 \pm 0.12$ & $(14.69 \pm 0.03)$ \\
L-Histidine & $0.43 \pm 0.02$ & $12.50 \pm 0.08$ \\
L-Isoleucine & $0.62 \pm 0.01$ & $0.45 \pm 0.01$ \\
L-Leucine & $0.77 \pm 0.01$ & $0.27 \pm 0.01$ \\
L-Phenylalanine & $0.54 \pm 0.02$ & $0.43 \pm 0.01$ \\
L-Valine & $0.80 \pm 0.01$ & $0.60 \pm 0.01$ \\
Tasteless & $(1.10 \pm 0.02)$ & $0.44 \pm 0.03$ \\
L-Lysine & $1.10 \pm 0.02$ & $(1.77 \pm 0.03)$ \\
L-Tyrosine & nd & $1.11 \pm 0.03$ \\
Total & $23.37 \pm 0.03$ & $0.66 \pm 0.03$ \\
\hline$a)$ Mean+standard deviation $(n=3) b)$ not detected & $27.91 \pm 0.02$ \\
\hline
\end{tabular}

Much more arginine, a bitter tasting amino acid, was present in the fruit body, about $5.1 \%(14.69 \mathrm{mg} / \mathrm{g})$, than in the core$\mathrm{mia}, 13.98 \mathrm{mg} / \mathrm{g}$. The bitter tasting amino acids in these two parts was higher than those in Shiitake $(9.53 \mathrm{mg} / \mathrm{g})$ and Enokitake $(9.98 \mathrm{mg} / \mathrm{g})$, but lower than in Hiratake $(27.02 \mathrm{mg} / \mathrm{g}$ ) (Kiribuchi, 1991). However, the bitterness in coremia and fruit body of $P$. abalonus could be masked by the sweet components and also by soluble sugars (Mau et al., 1998).

The coremia contained more of the essential amino acids threonine, isoleucine, leucine, and valine than the fruit body. On the other hand, no sulfur-containing amino acid was detected in this study. However, there remains a possibility that the amino acids which are not abundant in mushrooms were destroyed in the course of the experiment. In conclusion, the coremia and fruit body were similar in proximate composition but the two parts were considerably different in free amino acid compositions. Also, the protein contents in the two parts were similar in spite of the lower content of free amino acid in the coremia.

The taste of fruit body of $P$. abalonus might be more intense than Shiitake mushroom on the basis of total free amino acids and MSG-like amino acids shown in Table $2(27.91 \mathrm{mg} / \mathrm{g}$ and $6.29 \mathrm{mg} / \mathrm{g}$, respectively).

Acknowledgment The authors thank Mr. K. Otsuki, Special Forest Products Department, Forestry Experiment Station, Wakayama Research Center of Agriculture, Forestry and Fisheries, Japan, for supplying a photograph of Pleurotus abalonus.

\section{References}

Fujihara, S., Kasuga, A., Aoyagi, Y. and Sugahara, T. (1995). Nitrogen-to-protein conversion factors for some common edible mushrooms. J. Food Sci., 60, 1045-1047.

Jong, S.C. and Peng, J.T. (1975). Identity and cultivation of a new commercial mushroom in Taiwan. Mycologia, 67, 1235-1238.

Kagakugijutsucho Shigen-chousakai. (2001). 5 Tei Saishin Shokuhin Seibunhyo. Hitotsubashishuppan, Tokyo, pp. 36-73 (in Japanese).

Kazuno, C. and Miura, H. (1984). Constituents of Lyophyllum ulmarium (Studies on the constituents of edible fungi Part 1). Nippon
Shokuhin Kogyo Gakkaishi, 31, 649-655 (in Japanese).

Kazuno, C. and Miura, H. (1985). Chemical constituents of Pleurotus ostreatus (Studies on constituents of edible fungi Part 2. Nippon Shokuhin Kogyo Gakkaishi, 32, 338-343 (in Japanese).

Kinjo, K., Yaga, S., Sunagawa, M., Hayashi, H. and Akao, S. (1992). Study on the cultivation culture media of Basidiomycetes VII. Cultural characteristics of Pleurotus abalones Han., Chen et Cheng. Mokuzai Gakkaishi, 38, 393-399 (in Japanese).

Kiribuchi, T. (1991). Changes of free amino acid composition in fungi by sun or ultraviolet light irradiation. Nihon Kasei Gakkaishi, 42, 415-421 (in Japanese).

Kurasawa, S., Sugahara, T. and Hayashi, J. (1982). Proximate and dietary fibre analysis of mushrooms. Nippon Shokuhin Kogyo Gakkaishi, 29, 400-406 (in Japanese).

Mau, J.-L., Lin, Y.-P., Chen, P.-T., Wu, Y.-H. and Peng, J.-T. (1998). Flavor compounds in king oyster mushrooms Pleurotus eryngii. J. Agric. Food Chem., 46, 4587-4591.

Miller, O.K. (1969). A new species of Pleurotus with a coremioid imperfect stage. Mycologia, 61, 887-892.

Muratsubaki, T., Sayama, K. and Sato, K. (1986). Change of constituents in fruit body formation of Grifola frondosa (Studies on artificially cultivated Grifola frondosa Part 1). Nippon Shokuhin Kogyo Gakkaishi, 33, 181-185 (in Japanese).

Neda, H. and Furukawa, H. (1987). Pleurotus abalonus Han. Chen et Cheng, a newly cultivated mushroom in Japan. Trans. Mycol. Soc. Jpn., 28, 69-73 (in Japanese).

Ogawa, T. (1994). Chemistry and nutritional biochemistry of food constituents. Nippon Eiyo Syokuryou Gakkaishi, 47, 431-440 (in Japanese).

Ohga, S. (2000). Influence of wood species on the sawdust-based cultivation of Pleurotus abalonus and Pleurotus eryngii 175. J. Wood Sci., 46, 175-179.

Sugahara, T. (1995). Shokuhingaku Jikkensho. Tokyo, Kenpakusha, 43-71 (in Japanese).

Tabata, T. and Yamasaki, Y. (1995). Changes in constituents during fruit body formation of Yanagimatsutake Mushroom (Agrocybe cylindracea (Fr.) Maire). Nippon Shokuhin Kogyo Gakkaishi, 42, 607-610.

Takayama, C., Ohga, S. and Sakai, K. (1993). Sawdust-based cultivation and changes of culture mature degree of the edible mushroom, Pleurotus abalonus. J. Fac. Agric. Kyusyu Univ., 38, 19-33.

Tamaki, Y., Kinjo, K., Onishi, T., Hongo, F., Shinjo, C. and Yaga, S. (1997). Studies on the structure, function and utilization of water soluble polysaccharides from tropical mushroom 1. Elevation control of serum cholesterol in rats of Pleurotus abalones. Han. Chen et Cheng. Mokuzai Gakkaishi, 43, 90-95 (in Japanese).

Tamaki, Y., Kinjo, K., Uehara, M., Hongo, F., Tachibana, S. and Yaga, S. (2002). Studies on the structure, function and utilization of water soluble polysaccharides from tropical mushrooms II. Elevation control substance for serum cholesterol in rats from Pleurotus abalones. Mokuzai Gakkaishi, 48, 44-48 (in Japanese).

Terashita, T., Kono, M., Mishima, N., Obata, T. and Yamauchi, M. (1990). The proximate components, free and protein-bound amino acids in protein and $5^{\prime}$-GMP in fruit-bodies of Lentinus edodes Singer (Shiitake Mushroom) growth on artificial bed-blocks. Nippon Shokuhin Kogyo Gakkaishi, 37, 528-532 (in Japanese).

Yoshida, H., Sugahara, T. and Hayashi, J. (1986a). Changes in carbohydrates and organic acids during development of mycelium and fruit-bodies of Hiratake mushroom (Pleurotus ostreatus) Nippon Shokuhin Kogyo Gakkaishi, 33, 519-528 (in Japanese).

Yoshida, H., Sugahara, T. and Hayashi, J. (1987a). Changes in the contents of carbohydrates and organic acids in fruit body of HiratakeMushroom (Pleurotus ostreatus (Fr.) Quel) during development and post-harvest storage. Nippon Shokuhin Kogyo Gakkaishi, 34, 288 297 (in Japanese).

Yoshida, H., Sugahara, T. and Hayashi, J. (1986b). Changes in the contents of carbohydrates and organic acids in fruit-bodies of Shiitake-Mushroom (Lentinus edodes (Berk.) Sing.) during development and post-harvest storage. Nippon Shokuhin Kogyo Gakkaishi, 33, 414-425 (in Japanese).

Yoshida, H., Sugahara, T. and Hayashi, J. (1987b). Changes in carbohydrates and organic acid during development of mycelia and fruitbodies of Shiitake Mushroom (Lentinus edodes (Berk.) Sing.). Nippon Shokuhin Kogyo Gakkaishi, 34, 274-281 (in Japanese). 